\title{
マンモグラフィ検䛦精度管理中央委員会の現状と課題(3) 施設画像評価委員会の活動状況と問題点
}

\begin{tabular}{|c|c|c|c|c|}
\hline 岡崎 正敏 & 今村 & 惠子 & 遠藤登喜子 & 大貫 \\
\hline 王丸 明子 & 木村 & 千明 & 篠原 範充 & 寺田 \\
\hline 東野英利子 & 土橋 & 一慶 & 逸見 典子 & 藤井 \\
\hline 福田 & 堀田 & 勝平 & 森本 忠興 & \\
\hline
\end{tabular}

施設画像評価委員会のこれまでの活動状況と今後の問題点について述べる。同委員会が 書類審査，画像評価(ファントム画像評価，臨床画像評価)，線量測定の総合評価により施 設画像評価認定書を初めて発行したのは2001年 7 月 31日であった。その後，2005年10月ま での 4 年 4 ケ月間に施設画像評価は 596 台 $(1$ 施設複数台もあり, 評価後 3 年目の更新 76 台 も含む)に施行された。当初の 3 年間はスクリーン・フィルムシステムのみの評価であっ たが，2004年 4 月より一部ガイドライン改訂下で，新たにデジタルマンモグラフィの施設 画像評価拉よびスクリーン・フィルムシステムの再評価が開始された。デジタルマンモグ ラフィの評価は106台に施行され，うち評価 A が17台, B が78台(合格率 $89.7 \%$ )であった。 スクリーンシステムの合格率は $92 \%$ あった。問題点としては，再評価施設では評価 $\mathrm{A}$ が $\mathrm{B} ， \mathrm{~B}$ が $\mathrm{C}$ 一低下した施設数がかなり認められる。再評価を含めて新規申込み施設 数の伸び悩み，技術講習会の講師への負担増加，個人情報保護法への対応，画像評価申込 みの煩雑性，等が挙げられる。

Key words：施設画像評価委員会, ファントム画像評価, 臨床画像評価

\section{NPO 法人マンモグラフィ検診精度管理中 央委員会 (精中委) ・施設画像評価委員会設立 の背景}

平成 9 年, 日本乳癌検診学会は来るべきマンモ グラフィ乳癌検診に対応すべく，マンモグラフィ 検診精度管理中央委員会 (精中委: 平成16年 6 月

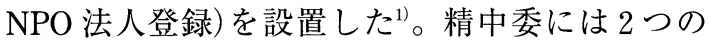
小委員会が設立された(図1)。1つはマンモグラ フィ診断機器, 線量, ファントム画像および臨床 画像, 等の評価・指導を行い, 施設認定を施行す

別冊請求先： ₹ 814-0180 福岡市城南区七隅 7-45-1 福岡大学医学部放射線医学教室 岡崎正敏

E-mail address : mokazaki@fukuoka-u.ac.jp
るマンモグラフィ施設画像評価委員会である。も う 1 つは医師に対するマンモグラフィ読影および 医師・診療放射線技師に対するマンモグラフィ撮 影法や機器管理の教育指導を行い, 評価認定事業 を施行する教育研修委員会である ${ }^{2)}$ 。平成 12 年 3 月 31 日付㴟生労働省老人保健課長名の老健第 65 号「がん予防重要健康教育及びがん検診実施のた めの指針」により, 平成12年 4 月 1 日からマンモ グラフィが正式に 50 歳以上の乳がん検診に導入さ れることとなった。検診の実施体制と実施機関の 基準として，以下の 3 項目が記載されている。

1)乳がん検診に当たっては精度管理等の検診の 実施体制が整っていることを用件とする。

2) 乳房 $X$ 線写真の撮影の実施機関は, 当該検 査を実施することに適格な撮影装置 [原則として 日本医学放射線学会の定める使用基準 ${ }^{3}$ を満たし 
NPO 法人 マンモグラフィ検診精度管理中央委員会 (精中委・理事長 森本忠興)
乳癌検診関連 6 学会

日本乳癌検診学会, 日本乳癌学会

日本医学放射線学会, 日本産婦人科学会

日本放射線技術学会, 日本医学物理学会
教育・研修委員会 (委員長 遠藤登喜子)

1. マンモグラフイ講習会・試験

医師 (読影)，診療放射線技師（撮影技術 - 管理）

に対して成績認定証発行

2.マンモグラフィ読影試験

講習会受講者に対するレベルアップ目的

3. マンモグラフイ指導者研修会

資格更新

ホームページ URL: http : //mammography.jp/
施設画像評価委員会 (委員長 岡崎正敏)

1. 画像評価

1) 書類審査

2 ) 画像評価

・フアントム(RMI156)画像評価

- 臨床画像評価

3 ) 線量測定 (ガラス線量計による)

2. 総合評価結果より

施設画像認定証発行

画質向上のサポートと再評価

図 1. 精度管理システム

ているものとし, 少なくとも適切な線量 $(3 \mathrm{mGy}$ 以下) 及び画像基準を満たすことが必要である] を備えるものとする。

3)マンモグラフィ検診精度管理中央委員会 (精 中委) が開催する乳房 X 線検查に関する講習会ま たはこれに準ずる講習会を修了した診療放射線技 師が乳房撮影を行うことが望ましい3)。1），2）， 3)の基準をクリアーできる施設を知ることが急務 となった。さらに平成16年 4 月 27 日の厚生労働省 通達「がん検診実施のための指針」の一部改正 (老 老発第0427001号)により，40歳代女性へのマンモ グラフィ検診の導入がなされた。これらの通達の 中には, 本邦では他の臓器癌検診にみられないシ ステムとして，このマンモグラフィ検診の精度管 理を担うシステムとして精中委の位置づけが示さ れている。

注: 平成15年 4 月, 平成14年度厚生労働科学研 究費補助金医療技術評価総合研究事業 (H14-医療 -064) 研究報告書-科学的根拠に基づく乳がん診療 ガイドライン作成に関する研究 (主任研究者 高 嶋成光先生)が発表された(2)。現在はやりの evi- dence base(科学的根拠)に基づいた医療行為の位 置づけを推奨の強さで表わし, 乳がん診療のガイ ドラインを作成したものである。乳癌検診に関し ては $2 つ の$ research questionが設問された。(1) “50歳代に対してマンモグラフィによる乳がん検 診は有用か”との設問に対する推奨度はグレード $\mathrm{A}$ (行うよう強く勧められる)で，“50歳以上にお いてマンモグラフィを用いた乳がん検診は死亡率 を減少させる”と記されている 対してマンモグラフィによる乳がん検診は有用 か”との設問に対する推奨度はグレード B(行う よう勧められる)で，“40歳代に対してマンモグラ フィによる乳がん検診は死亡率を減少させる”と 記されている。なお, 推奨の強さは A から D ま での 4 段階に分類されている。レベル A は最も 科学的根拠レベルの高い論文が存在するという意 味と理解すれば分かりやすい。

\section{2. マンモグラフィ施設画像評価委員会の構成}

同委員会の構成委員は関連 6 学会から推薦され た14名で構成されている。その内訳は日本乳癌検 
診学会 3 名, 日本医学放射線学会 3 名, 日本乳癌 学会 1 名, 日本放射線技術学会 4 名, 日本産婦人 科学会 1 名, 日本医学物理学会 1 名, 他, 日本乳 癌検診学会から顧問 1 名である7)。

\section{3. マンモグラフィ施設画像評価委員会の評価 内容とその変遷 $($ 図 2)}

施設画像評価は平成13年 4 月から申込みを受け 付けた。同年 7 月 31 日に最初の施設画像評価を行

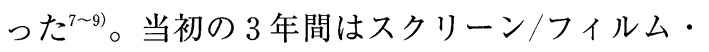
システム・マンモグラフィのみを対象とした。平 成16年 4 月よりデジタル系マンモグラフィ・シス テム画像の評価も開始した。なおスクリーン/フ イルム・システム以外のデジタル・マンモグラフ イについては, 新しいシステムが実用化されてき ていること, アナログ画像と同一評価方法で評価 することに未だ検討する必要があること等から， 適正な評価方法が確立されるまで時期尚早として 当初は除外された経緯が存在した。

\section{1)スクリーン/フィルム・システムの旧施設画像評}

\section{価法}

評価法としては, (1)書類審査, (2)画像評価, (3) 線量評価が行われ(図 1,2), (1)は品質管理の実 施状況などで, 書類審査の項目の他に臨床画像撮 影条件 (ターゲット, フィルター, 管電圧, 管電 流, 圧迫乳房厚, 圧迫厚, 撮影モード等)を後述 乳腺濃度状態別に記載することとなっている。(2) はファントム画像の視覚評価とデジタル評価, 臨 床画像の濃度計と視覚による評価, ファントム画 像評価は, 線維, 石灰化, 腫瘤の各模擬内蔵試料 の描出されるスコアー合計点が10点以上。ただ し, 線維の 4 群 ( 4 点), 石灰化の 3 群 ( 3 点), 腫 瘤の 3 群 ( 3 点)がそれぞれの得点に達しているこ と。(3)は RMI-156ファントム乳腺平均線量 $3 \mathrm{mGy}$ 以下であることをガラス線量計で確認する。臨床 画像の評価は乳腺分布濃度状態により, 乳腺散 在, 不均一高濃度, 高濃度 ${ }^{3)}$ の 3 種類の MLO 方 向の左右臨床画像 6 枚を各乳腺濃度別に評価し, その平均点で採点した
脂肪に置き換えられた乳房内に乳腺実質が散在し ている画像(図 3A), 不均一高濃度とは乳腺実質 内に脂肪が混在し, 不均一な濃度を呈する画像 (図 $3 \mathrm{~B})$, 高濃度 : 乳腺実質内に脂肪の混在がほとん どない，いわゆる dense breastの画像(図 3C)で ある ${ }^{7,8)}$ 。

旧臨床画像評価は本委員会関連 $3 \sim 5$ 名の評価 委員により採点した。臨床画像評価100点満点中 最も高い配点となった画質は乳腺濃度の 20 点, そ の他バック濃度, コントラスト, 粒状性, 鮮鋭度, アーチファクトは各々 8 点とし, 画質評価点が 100 点中 60 点を占めている。その配点と評価基準を表 1 に示す ${ }^{7,8)}$ 。

ポジショニングについては, (1)左右対称性, (2) 大胸筋の入り方, (3)乳腺後隙, (4)乳房下角の進展, (5)乳腺組織の進展性, (6)乳頭の側面性などを評価 $し^{2,3)}$, 各々 4 点満点である。フィルムの取扱いに ついては, (1)照射野の範囲(読影に支障がないよ う照射野が設定されているか)，(2)撮影情報の表 示 [撮影施設, 撮影年月日, 氏名(または生年月 日), なお撮影条件, 撮影技師も表示されている ことが望ましい], (3)フィルムマーク（腋窩部の乳 房より離れた場所に, 撮影方向と左右別の表示さ れているか)を評価し, これらも各々 4 点満点で 評価した。

臨床画像総合評価は平均乳腺線量 $3 \mathrm{mGy}$ 以 下, ファントム画像評価の評価スコア 10 点以上を クリアーした施設で, 臨床画像総合評価は 3 種類 の画像の得点を平均し, 小数点以下は切り捨て た。100点満点中 88 点以上を $\mathrm{A}, 76$ ～87点を $\mathrm{B}, 75$ 〜 64点を $\mathrm{C}, 63$ 点以下を $\mathrm{D}$ とた。なお, 評価 $\mathrm{A}, \mathrm{B}, \mathrm{C}, \mathrm{D}$ とは以下のごとく位置づけられて いる。評価 $\mathrm{A}$ は検診マンモグラムとして申し分 ない。Bは検診マンモグラムとして適当である が，多少の改善点がある。C は検診マンモグラム として適当とは言えず，かなりの改善点がある。 $\mathrm{D}$ は検診マンモグラムとしては不適切である。根 本的な改善が必要である。

評価 $\mathrm{A}, \mathrm{B}$ を合格, 評価 C, D を不合格として, $\mathrm{A}, \mathrm{B}$ 施設にはマンモグラフィ検診施設画像認定 


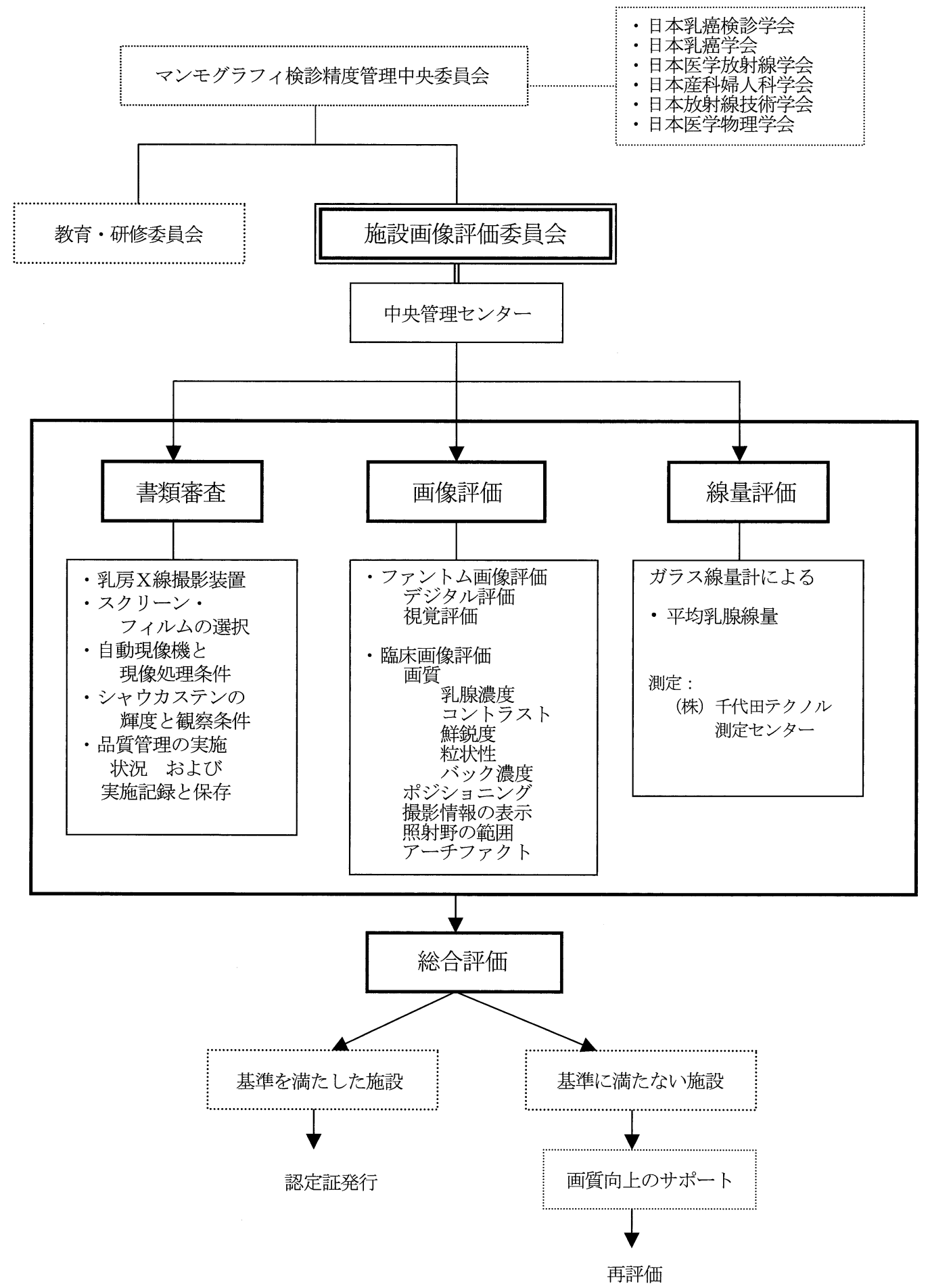

※ 総合評価はすべて施設画像評価委員会中央管理センターで行う。

図 2. 施設画像評価のシステム 


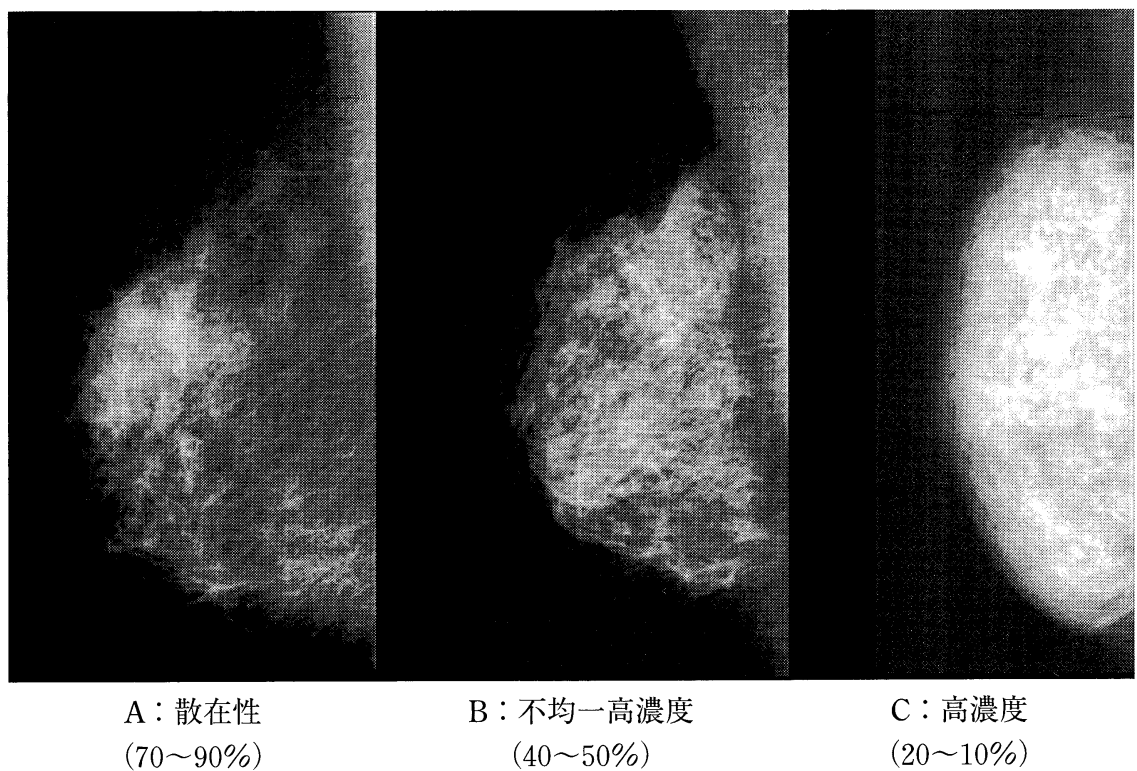

図 3. 乳房の構成

書を交付した ${ }^{7 \sim 9)}$ 。C, D の施設には結果報告書に 前述, 書類審査, 画質評価, 線量評価の個々の項 目につき改良すべき点を詳細に記載した指導書を 送付している。

\section{2)デジタル系マンモグラフィ・システム系を含め}

\section{た新しい施設画像評価法}

デジタル系マンモグラフィ・システムの種々の デー夕をもとに従来のアナログ系システム画像の 画像評価基準を一部改訂し, 新基準のもと両系シ ステムとも同一の評価基準を審査することとなっ $た^{10,11)}$ 。施設画像評価の申込み要項は従来と変わ らない。ただし，一部従来と異なる点は，日常管 理の精度管理記載簿 ( 3 ケ月分: 日時は委員会か ら任意に指定)を提出すること。日本医学放射線 学会が定めるマンモグラフィ仕様基準を満たされ ない古い装置の使用を最初の 3 年間暫定的に認め ていたが， 3 年経過した2004年 4 月からは認定し ないこととした。

主な評価基準の改訂点は, (1)従来のファントム と異なる ACR-156およびファントムステップフ アントムによるファントム画像評価, i ) 撮影法 を統一した評価, ii ) 視覚評価, iii) デジタル評価,
(2)臨床画像評価の点数も一部変更した。画質は旧 基準では 100 点満点中 60 点であったものが, 新基 準では56点とした。一方，フィルムの取扱いを 12 点から16点に増点した。画質56点の主な変更点 (表 2) は乳腺濃度を 20 点から 12 点に減点，コントラス 卜を乳腺内と乳腺外にわけ, 従来の 8 点を各々 8 点の計16点に増点, アーチファクトを 4 点減点で ある。画質の 4 点減点分をフィルムの取扱い項に 増点した。その詳細は精中委のホームページ http : //www.mammography.jp に掲載ずみである。

\section{4. 施設画像評価の更新}

施設画像評価は 3 年に一度更新されることとな っている ${ }^{12)}$ 。前述したように, 平成13年 7 月の最 初の施設画像評価から 3 年以上経過した認定施設 (平成17年10月まで) は99施設である。うち前回評 価 $\mathrm{A}$ の 60 施設中 9 施設が, 評価 $\mathrm{B}$ の 25 施設中 14 施設が未更新である。これらの未更新施設への対 応策として施設画像評価委員会では，以下のよう な $3 つ の$ 対応策を決定した。

1) 認定期限の半年前には当該施設に認定画像評 価の更新に関する事項を通知することが再確認さ れた。 
表 1. 旧臨床画像評価の配点とその評価基準

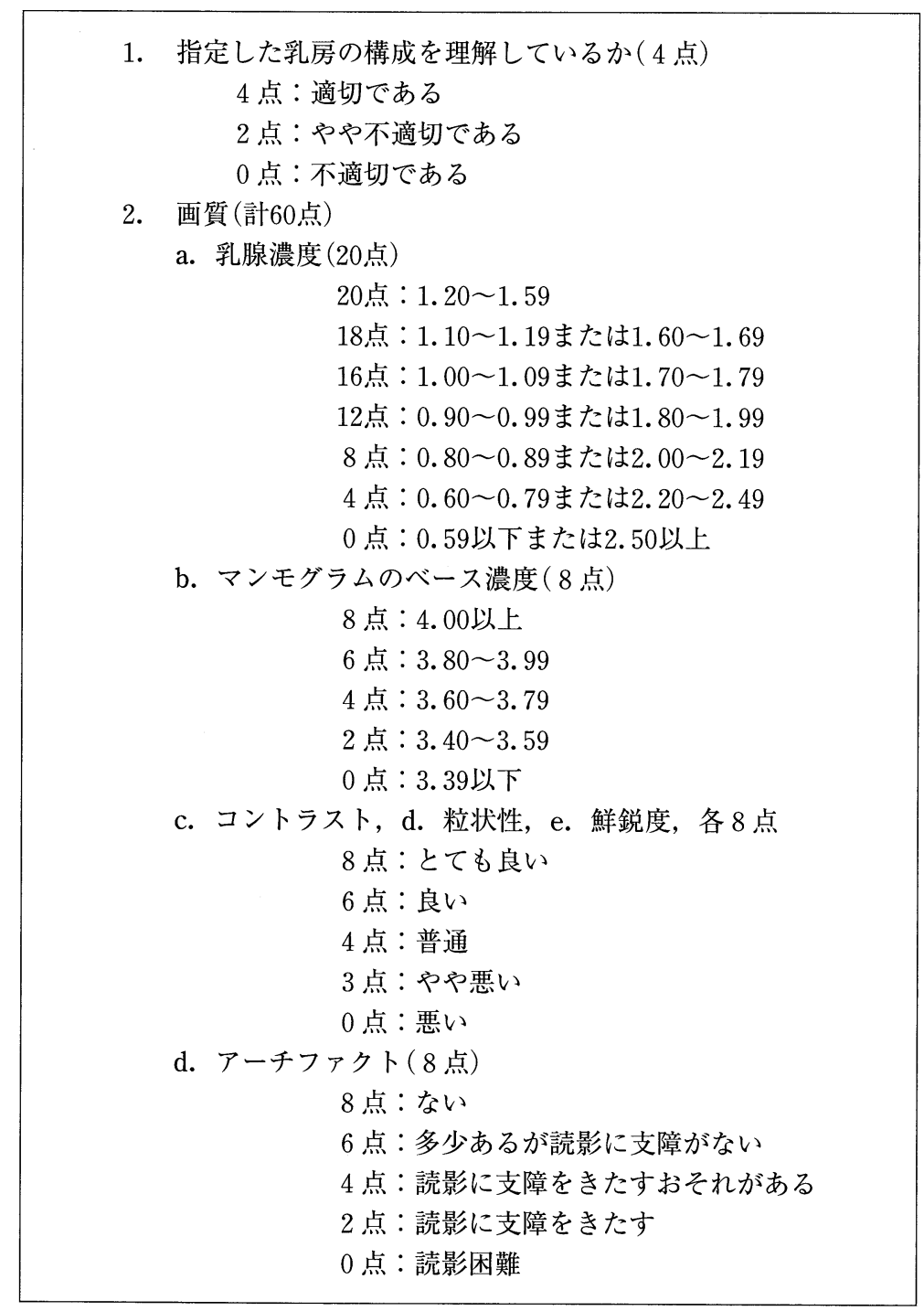

表 2. 画質評価の変更 $(60$ 点 $\Rightarrow 56$ 点)

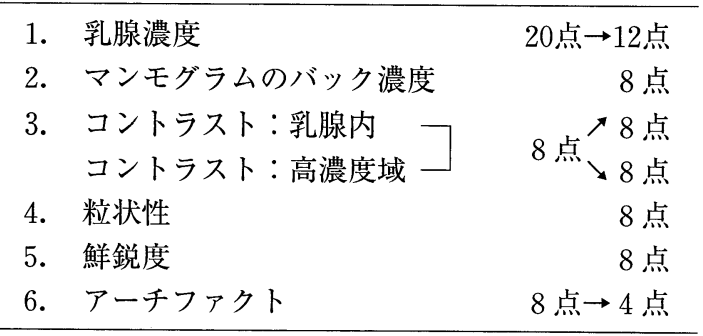

2)認定期限を 1 年過ぎるまでに再評価を受けた 施設の更新は認めるが， 1 年以上過ぎても再評価
表 3. 施設・画像評価による評価結果

$\left.\begin{array}{cccc}\hline \text { 評価 } & \text { 施設数 } & \text { 台数 } & (\text { デジタル }) \\ \hline \mathrm{A} & 215 & (228) & (17) \\ \mathrm{B} & 306 & (320) & (78) \\ \mathrm{C} & 39 & (40) & (11)\end{array}\right\}$ 約 $92 \%$

(2001.6～2005.10：568施設) ムページの認定施設名の項からも削除することと 
表 4. ホームページに公開されている全国地域別の 施設画像認定施設数 (506)施設)

\begin{tabular}{lc}
\hline \multicolumn{1}{c}{ 地区 } & 認定施設数 \\
\hline 北海道 & 12 \\
東北 ( 6 県 $)$ & 75 \\
関東 $(1$ 都 6 県 $)$ & 124 \\
中部 $(9$ 県 $)$ & 99 \\
近畿 $(2$ 府 5 県 $)$ & 104 \\
中国 $(5$ 県 $)$ & 32 \\
四国 $(4$ 県 $)$ & 21 \\
九州 $(8$ 県 $)$ & 39 \\
\hline \multicolumn{1}{c}{ 計 }
\end{tabular}

(平成17年10月11日現在)

した。

3) 前述の事項をすべて認定施設に書面で通知す る。ホームページに同様の通告を行う。

\section{5. 施設画像評価による評価結果 (表 3)}

施設画像評価が施行された596台中, 評価 A : 228 台 $(38.3 \%)$, B：320台 $(53.7 \%), C ： 40$ 台 (6.7\%), D：8台(1.3\%)であった。うちスクリ ーン/フィルム・システムの合格率は $92 \%(\mathrm{~A}$ : 43\%, B : 49\%)であった。デジタル・システム のそれは89.7\% (A：16.1\%, B：73.6\%)であっ た。ホームページに公開されている県別の施設画 像認定施設数を表 4 に示す。各地区により認定施 設に著しい差があることが分かる。

\section{6. 現在の問題点とその対応}

1) 施設画像評価の更新評価を受けた施設のラン クが $\mathrm{A}$ から $\mathrm{B}(51$ 施設中更新後 $\mathrm{A}$ はわずかに 8 施 設， $\mathrm{B} ， 25$ 施設中更新後 $\mathrm{A}$ は 5 施設), $\mathrm{B}$ から $\mathrm{C}$ に下がった施設画像も多々認められる。初回の申 請時よりもポジショニングやコントラスト項目で 減点された施設が多い印象を受ける。

2) 再評価を含めて画像評価の申請数は伸び悩ん でいる。評価台数はこれまで約 600 台で未評価台 数は $4 \sim 5$ 倍存在する。講習会, 学会, 研究会, ホームページなどでのさらなる啓蒙を推進すると ともに各都道府県の成人病管理指導協議会「乳が
ん部会」への働きかけが必要と考える。

3）個人情報保護法への対応

施設画像評価に際し，提出されるマンモグラフ イでの個人情報 (ID，名前を含めた各種条件など) をいかに取り扱うかが問題となった。

\section{[NPO 法人精中委の基本姿勢 $]$}

(1)マンモグラフィについては，その評価以外に は一切使用しない。

(2)マンモグラフィについては, 評価終了と同時 に即刻返却する。

(3)マンモグラフィについては, 各評価項目の適 否以外の目的には使用しない。

(4)評価に使用するマンモグラフィの個人情報は 一切記載保存しない。

\section{[具体的な事例]}

(1)各施設の個人情報保護に関する取扱いに準ず る。

(2)上記に関連して，個人情報保護を目的とし て,「ID」，[各種条件焼き付け］部を分黒テープ にて目隠しして，個人情報が漏れないような処理 を施して提出が許されるのであれば，その旨を記 述して提出していただく。

\section{7. 施設画像評価の実施}

現在まで, 画像評価は名古屋でしか施行するこ とができなかった。書類審査, ファントム画像評 価に始まる一連の評価過程は煩雑で今までは限ら れた評価委員の手仕事で施行されてきた現状であ る。今後の対応は現在模索中である。

\section{8. 施設画像評価申込みの煩雑性}

申込み書類の煩雑性に対する多数の苦情が委員 会に寄せられている。その対応策として，委員会 ではインターネットによる施設画像評価の申込み が可能なホームページを開設した。しかしなが ら，現在のところ，電子ファイルのみによる申込 みは不可能である。精中委および関連 6 学会のホ ームページにこの旨掲載している。なお，従来の 申込み用紙による申請も可能であることも確認さ れている。 


\section{まとめ}

1)施設画像委員会の活動状況と山積みされてい る問題点について述べた。

2) NPO 法人取得後, NPO 法人精中委名古屋事 務所も開設された。学会員の積極的参加を期待し たい。

3)同事務所をキーステーションにホームペー ジ，インターネットを使った施設画像評価の質お よび量の向上を今後計るつもりである。

\section{【文 献】}

1) 森本忠興, 石田常博, 福田 護, 他：マンモグ ラフィを導入した乳癌検診システムのガイドラ イン (日本乳癌検診学会ガイドライン作成委員会 編)。篠原出版, 東京, 1997, pp. 1-38

2 ）マンモグラフィ検診精度管理中央委員会 : マン モグラフィ検診精度管理中央委員会の役割につ いて. 日乳癌検診学会誌, $10: 71-87,2001$

3 ）大内憲明編：マンモグラフィによる乳がん検診 の手引き——精度管理マニュアル．改訂第 2 報. 日本医事新報社，2001

4) 高嶋成光, 池田 正, 大内憲明, 他：科学的根 拠に基づく乳がん診療ガイドライン作成に関す る研究 (H14-医療-064). 厚生労働科学研究費補 助金 (医療技術評価総合研究事業) 総括研究報告 書兼分担報告書，2003
5 ) Shapiro S, Venet W, Strax P, et al: Ten- to fourteen-year effect of screening on breast cancer mortality. J Natl Cancer Inst, $69: 349-$ 355, 1982

6) Tabar L, Fagerberg CJ, Gad A, et al: Reduction in mortality from breast cancer after mass screening with mammography. Randomized trial from the Breast Cancer Screening Working Group of the Swedish National Board of Health and Welfare. Lancet $13 ; 1$ (8433) : 829-32, 1985

7 ）マンモグラフィ検診精度管理中央委員会：マン モグラフィ検診精度管理中央委員会報告書(第 1 版)——平成10年度 13 年度の活動状況. 2001年 3 月

8 ）岡崎正敏, 石栗一男, 今村惠子, 他：マンモグ ラフィ検診精度管理中央委員会 (精中委) ・施設 画像評価委員会の活動状況. 日本がん検診・診 断学会誌, $10: 176-182,2003$

9 ) Morimoto T, Okazaki M, Endo T: Current status and goals of mammographic screening for breast cancer in Japan. Breast Cancer, 11:73-81，2004

10）堀田勝平：デジタル画像を含む新画像基準の技 術的対応. 日乳癌検診学会誌, $14: 227-235,2005$

11）堀田勝平：新画像評価基準のアナログーデジタ ル両システムへの適用. INNERVISION，20：13 $-18,2005$

12）王丸明子, 寺田 央, 堀田勝平, 他：施設画像 評価委員会の現状と再評価施設における成果. 日乳癌検診学会誌，14：48-53，2005 